\title{
Primary Cardiac Tumors and Long-Term Results of Surgery: A 38-Year Experience in 81 Patients
}

\author{
Primer Kardiyak Tümörler ve Cerrahinin Uzun Dönem Sonuçları: 81 Hastaya Ait 38 Yıllık \\ Tecrübe
}

\author{
(D) Ulaş Kumbasar1, (1) Ahmet Aydın², (1) Timuçin Sabuncu33, (1) Murat Güvener2, (1) Mustafa Yılmaz², (1) Rıza Doğan¹, (D) Metin Demircin² \\ ${ }_{1}^{1}$ Hacettepe University Faculty of Medicine, Department of Thoracic Surgery, Ankara, Turkey \\ 2 Hacettepe University Faculty of Medicine, Department of Cardiovascular Surgery, Ankara, Turkey \\ 3 University of Health Sciences, Behçet Uz Children's Diseases and Thoracic Surgery Training and Research Hospital, Pediatric Cardiovascular \\ Surgery, izmir, Turkey
}

\section{Abstract}

Objectives: In this study, we examined our 38 years of institutional experience with 81 patients operated for primary cardiac tumor.

Materials and Methods: Among the 81 patients included, 95\% $(n=77)$ had benign tumors and 5\% $(n=4)$ had malignant tumors. Benign tumors were myxomas $(n=66,81.5 \%)$, rhabdomyomas $(n=9,11.1 \%)$ and papillary fibroelastomas $(n=2,2.5)$. Malignant tumors included angiosarcomas $(n=2$, $2.5 \%)$ and rhabdomyosarcomas $(n=2,2.5 \%)$. Common symptoms of admission were dyspnea (49.4\%), palpitation (30.9\%) and systemic embolization (14.8\%). Tumors originated from the left atrium in 61 cases (75.3\%), right atrium in 12 cases (14.8\%), right ventricle in 5 cases (6.2\%) and left ventricle in 3 cases (3.7\%). The surgical method was uniatrial in 47 patients (58\%). Bilateral atriotomy was performed in 26 patients $(32 \%)$. The incidence of postoperative complication was $14.8 \%(n=12)$.

Results: In-hospital (30 day) mortality was $4.9 \%(n=4)$. The survival of other benign tumors and malignant tumors were poorer than the patients with myxomas.

Conclusion: Surgical resection of primary cardiac tumors with negative margins have excellent long-term survival which are similar to general population.

Key Words: Intracardiac Tumors, Surgical resection, Survival

\section{Öz}

Amaç: Bu tek merkezli çalışmada, kurumumuzun primer kardiyak tümörler nedeniyle opere edilmiş 81 hastadaki 38 yıllık tecrübesini gözden geçirdik. Gereç ve Yöntem: Bu çalışmaya dahil edilen 81 hastanın \%95'inde $(n=77)$ benign \%5'inde $(n=4)$ ise malign tümörler bulunmaktaydı. Benign tümörler, miksomaları $(n=66, \% 81,5)$, rabdomyomaları $(n=9, \% 11,1)$ ve papiller fibroelastomaları $(n=2, \% 2,5)$ içeriyordu. Malign tümörler ise anjiosarkomaları $(n=2, \% 2,5)$ ve rabdomyosarkomaları $(n=2, \% 2,5)$ kapsamaktaydı. Başvuru sırasında en sık görülen semptomlar disepne $(\% 49,4)$, çarpıntı $(\% 30,9)$ ve sistemik embolizasyondu $(\% 14,8)$. Tümörler, 61 olguda $(\% 75,3)$ sol atriumdan, 12 olguda $(\% 14,8)$ sağ atriumdan 5 olguda $(\% 6,2)$ sağ ventrikülden ve 3 olguda $(\% 3,7)$ sol ventrikülden köken alıyordu. Cerrahi yaklaşım, 47 olguda (\%58) uniatriyaldi. Bilateral atriyotomi 26 hastada (\%32) uygulandı. Postoperatif komplikasyon insidansı \%14,8 $(n=12)$ olarak tespit edildi.

Bulgular: Hastane içi ölüm (30 günlük), \%4,9'du ( $n=4)$. Miksomalarla karşılaştırıldığında, diğer benign ve malign tümörlerin sürvilerinin karakteristiklerinin daha kötü olduğu görüldü.

Sonuç: Primer kardiyak tümörlerin, negatif sınırlar ile cerrahi rezeksiyonu, çok iyi uzun dönem sağkalım sağlamaktadır; kardiyak miksomalı hastaların sağkalım karakteristikleri genel popülasyon ile benzerlik göstermektedir

Anahtar Kelimeler: İntrakardiyak Tümörler, Cerrahi Rezeksiyon, Sağkalım

Yazışma Adresi/Address for Correspondence: Dr. Ulaş Kumbasar

Hacettepe University Faculty of Medicine, Department of Thoracic Surgery, Ankara, Turkey

Tel.: +90 5333571075 E-posta: ulaskumbasar@gmail.com ORCID ID: orcid.org/0000-0003-0616-1326

Geliş Tarihi/Received: 19.10.2018 Kabul Tarihi/Accepted: 07.03.2019

๑Telif Hakkı 2019 Ankara Üniversitesi Tıp Fakültesi

Ankara Üniversitesi Tıp Fakültesi Mecmuası, Galenos Yayınevi tarafından yayınlanmıştır.

Yayınlanan tüm içerik CC BY-NC-ND lisansı altındadır. 


\section{Introduction}

Primary cardiac tumors are unique and have an incidence of $0.0017 \%$ to $0.02 \%$. They constitute $5 \%$ to $10 \%$ of all neoplasms of the heart (1). Seventy-five per cent of primary tumors are benign. Among them, myxoma is the most frequent tumor type (50\% of cases). Other benign tumors or the heart are papillary fibroelastomas, fibromas, hemangiomas, teratomas, and rhabdomyomas. Malignant tumors of the heart include sarcomas, which angiosarcoma being the most common histologic type $(2,3)$. This report summarizes our 38 years of institutional experience with 81 patients operated for primary cardiac tumor with comprehensive analysis of patient characteristics, mean survival and prognostic indicators of long-term survival.

\section{Material and Methods}

Between January 1977 and January 2015, a total of 81 patients were surgically treated at our institution with the diagnosis of primary heart tumors. Our Institutional Research Committee approved the study. Data is obtained from intensive care observation charts and also from patient records. Ninety-five per cent of the patients $(n=77)$ had benign tumors and $5 \%(n=4)$ had malignant. Benign tumors were myxomas $(n=66,81.5 \%)$, rhabdomyomas $(n=9,11.1 \%)$ and papillary fibroelastomas $(n=2$, $2.5 \%)$. Malignant tumors included angiosarcomas $(n=2,2.5 \%)$ and rhabdomyosarcomas $(n=2,2.5 \%)$. These patients included 40 males (49.4) and 41 females (50.6\%). The mean age at tumor diagnosis was $37.2 \pm 21.7$ years (range $0-80$ years). Commonest symptoms were dyspnea (49.4\%), palpitation (30.9\%) and systemic embolization (14.8\%).

\section{Diagnosis}

Patients were diagnosed by transthoracic and/or transesophageal echocardiography. Three patients (3.7\%) had coronary artery disease necessitating concomitant bypass grafting. Tumors originated from the left atrium (LA) in 61 cases (75.3\%), right atrium (RA) in 12 cases (14.8\%), right ventricle in 5 cases $(6.2 \%)$ and left ventricle in 3 cases (3.7\%). While patients with tumors of the LA clinically mimicked mitral stenosis and/ or regurgitation, patients with tumors of the RA presented with tricuspid valve pathologies. Preoperative characteristics of patients are depicted in Table 1.

\section{Surgical Technique}

Our standard surgical method was via median sternotomy. Cardiopulmonary bypass (CPB) was also conducted with moderate hypothermia. Myocardium was routinely protected with cold antegrade blood cardioplegia. The surgical approach was uniatrial in 47 patients (58\%). Bilateral atriotomy was performed in 26 patients (32\%). Ventricular tumors were resected via aortotomy or ventriculotomy. Total removal of the tumor was performed, and the created defect was repaired directly $(n=63,78.8 \%)$ or with prosthetic material $(n=18$, $22.2 \%$ ). Seven patients were treated with combined procedures for additional coronary artery disease, mitral valve disease and atrial septal defect. Diagnosis was confirmed by histopathologic examination in all patients. Tumor size ranged between 1.2 and $10 \mathrm{~cm}$ (mean: $3.5 \mathrm{~cm}$ ). Perioperative characteristics are summarized in Table 2.

\section{Statistical Analysis}

Statistical analyses were performed with IBM SPSS for Windows version 22.0 statistical software. Continuous variables are presented as mean \pm standard deviation and categorical variables as frequencies and percentages. Survival probabilities

\begin{tabular}{|c|c|c|}
\hline Variable & No of patients & $\%$ \\
\hline Tumor pathology & - & - \\
\hline Myxoma & 66 & 81.4 \\
\hline Rhabdomyoma & 9 & 11.1 \\
\hline Papillary fibroelastoma & 2 & 2.5 \\
\hline Angiosarcoma & 2 & 2.5 \\
\hline Rhabdomyosarcoma & 2 & 2.5 \\
\hline Clinical symptoms & - & - \\
\hline Dyspnea & 40 & 49.4 \\
\hline Palpitation & 25 & 30.9 \\
\hline Embolic events & 12 & 14.8 \\
\hline CNS & 9 & 11.1 \\
\hline Peripheral & 2 & 2.5 \\
\hline Pulmonary & 1 & 1.2 \\
\hline Syncope & 5 & 6.2 \\
\hline NYHA class & - & - \\
\hline I & 36 & 44.4 \\
\hline II & 29 & 35.9 \\
\hline III & 12 & 14.8 \\
\hline IV & 4 & 4.9 \\
\hline Tumor location & - & - \\
\hline Left atrium & 61 & 75.3 \\
\hline Right atrium & 12 & 14.8 \\
\hline Right ventricle & 5 & 6.2 \\
\hline Left ventricle & 3 & 3.7 \\
\hline Associated lesions & - & - \\
\hline Mitral stenosis/regurgitation & 28 & 34.6 \\
\hline Tricuspid stenosis/regurgitation & 7 & 8.6 \\
\hline Coronary artery disease & 6 & 7.4 \\
\hline ASD & 2 & 2.5 \\
\hline
\end{tabular}

CNS: Central nervous system; NYHA: New York Heart Association; ASD: Atrial septal defect 
were given by Kaplan Meier product limit estimation. Log rank test was used to determine the difference between the groups. Significance value was considered as 0.05 .

\section{Results}

The incidence of postoperative complication was 14.8\% $(n=12)$, including mediastinitis, cardiac arrhythmia, renal insufficiency requiring dialysis, pneumonia and pericardial effusion (Table 3). Overall, 10 patients (12.3\%) died during the

\begin{tabular}{lll}
\hline Table 2: Perioperative characteristics & & \\
\hline Variable & No.of patients & $\%$ \\
\hline Surgical approach & & \\
\hline Left atriotomy & 35 & 43.2 \\
\hline Bilateral atriotomy & 26 & 32.1 \\
\hline Right atriotomy & 12 & 14.8 \\
\hline Ventriculotomy & 6 & 7.4 \\
\hline Aortotomy & 2 & 2.4 \\
\hline Surgical repair & & \\
\hline Direct & 63 & 78.8 \\
\hline Prosthetic material & 18 & 22.2 \\
\hline Concomitant procedures & & \\
\hline CABG & 3 & 3.7 \\
\hline ASD repair & 2 & 2.4 \\
\hline MVR & 2 & 2.4 \\
\hline Postoperative complication & 12 & 14.8 \\
\hline In-hospital mortality & 4 & 4.9 \\
\hline Recurrence & 4 & 4.9 \\
\hline $\begin{array}{l}\text { CABG: Coronary artery bypass grafting, ASD: Atrial septal defect, MVR: Mitral valve } \\
\text { replacement }\end{array}$ & \\
\hline
\end{tabular}

follow-up period. In-hospital (30 day) mortality was $4.9 \%(n=4)$. Two patients died due to persistent right ventricular dysfunction. We had one early mortality due to myocardial infarction. One patient died due to sepsis complicated by multiple organ failure. Recurrence of primary cardiac tumors were detected in 4 patients ( 3 myxoma and 1 rhabdomyoma) during follow-up. One patient who had Carney complex syndrome presented with multiple myxomas in both atriums and recurred two times in different locations, 6 and 8 years after first resection. Followup could be established in 77.7\% of patients (mean: 22 years). Overall survival was $88 \%$ and $81 \%$ at 5 and 10 years respectively. Univariate analysis showed that the survival of benign tumors other than myxoma and malignant tumors were poorer than the patients with myxomas in the long-term (Figure 1). However, the effects of gender, use of prosthetic material for defect closure and tumor location on survival were found to be statistically insignificant (Table 4).

\section{Discussion}

Primary cardiac tumors are unique and a limited number of surgeons have experience about their management. The first successful surgical treatment was performed by Crafoord

\begin{tabular}{ll}
\hline Table 3: Postoperative complications & \\
\hline Complication & $\mathbf{n}(\%)$ \\
\hline Atrial fibrillation & $7(58.3)$ \\
\hline Mediastinitis & $1(8.3)$ \\
\hline Pericardial effusion & $1(8.3)$ \\
\hline Renal failure & $1(8.3)$ \\
\hline Transient ischemic attack & $1(8.3)$ \\
\hline Lung abscess & $1(8.3)$
\end{tabular}

Table 4: Results of the survival analyses

\begin{tabular}{|c|c|c|c|c|c|c|c|c|}
\hline & & Mortality & $\begin{array}{l}1 \text { year } \\
\text { survival }\end{array}$ & $\begin{array}{l}3 \text { year } \\
\text { survival }\end{array}$ & $\begin{array}{l}5 \text { year } \\
\text { survival }\end{array}$ & $\begin{array}{l}10 \text { year } \\
\text { survival }\end{array}$ & $\begin{array}{l}\text { Mean survival } \\
\text { (years) }\end{array}$ & $\mathbf{p}$ \\
\hline All patients $(n=81)$ & & 10 & 0.903 & 0.882 & 0.882 & 0.816 & 22 & - \\
\hline \multirow{4}{*}{ Surgical approach } & Left atriotomy & 3 & 0.909 & 0.909 & 0.909 & 0.909 & 22 & \multirow{4}{*}{$<0.001$} \\
\hline & Bilateral atriotomy & 3 & 0.902 & 0.902 & 0.902 & 0.789 & 15.5 & \\
\hline & Right atriotomy & 1 & 1 & 1 & 1 & 0.800 & 23.7 & \\
\hline & Ventriculotomy & 3 & 0.500 & 0 & 0 & 0 & 1.5 & \\
\hline \multirow{2}{*}{ Surgical repair } & Direct & 10 & 0.889 & 0.864 & 0.864 & 0.793 & 21.4 & \multirow{2}{*}{0.240} \\
\hline & Prosthetic material & - & 1 & 1 & 1 & 1 & - & \\
\hline \multirow{2}{*}{ Gender } & Male & 5 & 0.901 & 0.901 & 0.901 & 0.788 & 20.2 & \multirow{2}{*}{0.802} \\
\hline & Female & 5 & 0.905 & 0.870 & 0.831 & 0.831 & 23.8 & \\
\hline \multirow{2}{*}{ Tumor location } & Left atrium & 6 & 0.904 & 0.904 & 0.904 & 0.848 & 21 & \multirow{2}{*}{0.526} \\
\hline & Others & 4 & 0.894 & 0.813 & 0.813 & 0.723 & 21.2 & \\
\hline \multirow{3}{*}{ Tumor histology } & Malignant & 3 & 0.667 & 0.333 & 0 & 0 & 2.9 & \multirow{3}{*}{$<0.001$} \\
\hline & Myxoma & 6 & 0.921 & 0.921 & 0.921 & 0.872 & 23.3 & \\
\hline & Non-myxoma & 1 & 0.875 & 0.875 & 0.875 & 0.875 & 14.4 & \\
\hline
\end{tabular}




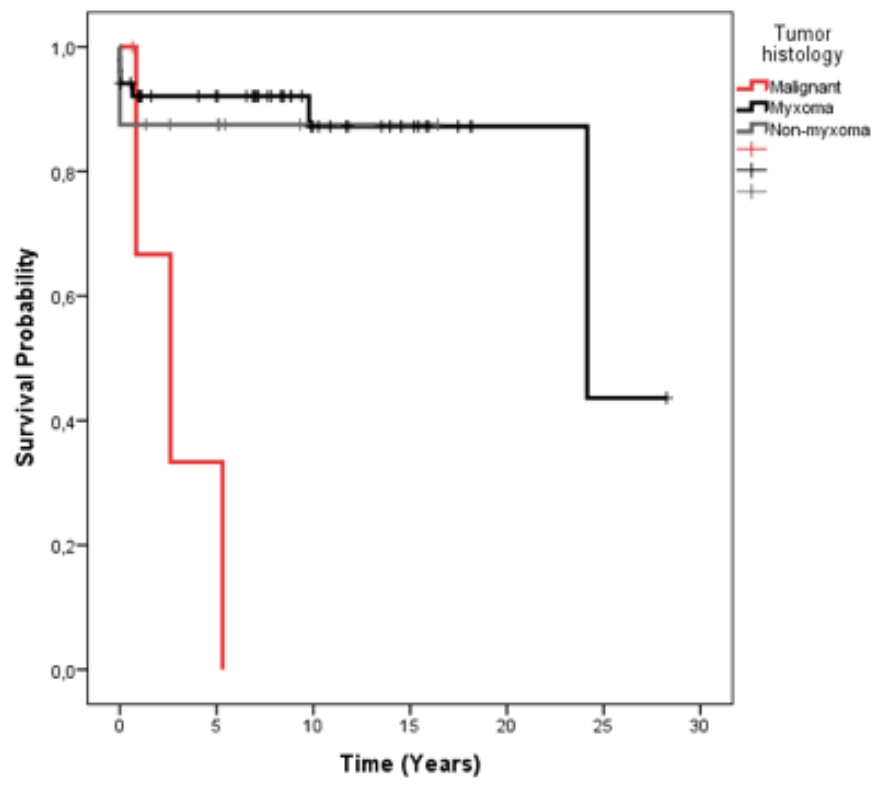

Figure 1: Survival analysis of primary cardiac tumors

in 1955. There are very few studies which observed the longterm survival characteristics of these patients $(2,4)$. Most of the reports have focused on cardiac myxoma patients (5-7). Our purpose was to show 38 years of experience with both detailed patient characteristics, surgical treatment methods and prognostic markers of long-term survival.

Generally, clinical presentation of these tumors is in the adulthood period, mainly at the sixth decade, with a female gender dominance, in contrast to our study which constitutes younger patients with almost equivalent gender distribution $(7,8)$. These patients often present with cardiovascular symptoms or embolic events due to the embolism of the tumor. Cardiovascular related symptoms are often determined mainly by anatomic situation of the and include valve dysfunction caused by direct obstruction, interruption of coronary flow, impaired myocardial contractility, conduction system abnormalities causing arrhythmias and pericardial effusion (911). Our patients confirm to the clinical symptom distribution. Regarding the location of the tumor, around $75 \%$ was in the left atrium ( $75.3 \%$ in our series), $15 \%$ to $20 \%$ in the right atrium ( $14.8 \%$ in our series), and $3 \%$ to $4 \%$ in the ventricles $(9.9 \%$ in our series) $(7,8)$.

Echocardiography is the most ideal diagnostic method. It is easy to perform, non-invasive, widely available and gives valuable information about the location, motion, shape, size and haemodynamic consequences of the tumors. Computed tomography (CT) and magnetic resonance (MRI) are other imaging modalities that gives us further diagnostic information when needed and for staging of malignant tumors $(10,12,13)$.

In general, therapy of benign cardiac tumors is surgical resection. Papillary fibroelastomas are surgically removed in cases of large $(>1 \mathrm{~cm})$ and/or mobile tumors. Rhabdomyomas may not require surgical management as they may regress spontaneously. Surgical resection is performed if the tumors are large or causes mechanical or hemodynamic complications. Management of choice in primary cardiac sarcomas is surgical resection, since they tend to infiltrate the myocardium rapidly or cause obstruction of the cardiac chambers $(10,11,14,15)$. In our series, myxomas and sarcomas were resected as soon as the diagnosis is made. Regarding the papillary fibroelastomas and rhabdomyomas, only the patients who had undergone resection due to size of the tumor or haemodynamic consequences were included in the study. The optimal surgical method for total excision of intracardiac tumors is debatable. Most studies describe surgical approaches for patients who underwent resection for cardiac myxoma, since other primary cardiac tumors are very rare $(6,7,16,17)$. While the LA or RA approach provides a straightforward access to the tumors, biatrial approach provides better exposure and easy extraction of the tumor. The trans-septal approach through RA also gives good access to the tumor and allows wide inspection $(18,19)$. Besides, in recent reports, minimally invasive surgical techniques and robotically assisted excisions are used for selected patients $(20,21)$. In our experience, we approached small atrial tumors with left or right atriotomy. We use biatrial approach for patients who had large tumors located in the interatrial septum. Left and right ventricular tumors were resected via aortotomy $(n=2)$ or left ventriculotomy $(n=1)$ and via right ventriculotomy $(n=5)$, respectively. There are some requirements to minimize recurrences and to achieve complete cure. Complete resection should be performed with enough extent of healthy tissue at the margins and when the remaining defect is extensive, it should be reconstructed with prosthetic material $(7,22)$.

Following the first cardiac tumor recurrence described by Gerbode, many reports have been published regarding with multiple recurrences of myxomas (23-25). Although the recurrence risk is nearly $3 \%$ for sporadic myxomas, it is around $10 \%$ in familial cases. The risk almost doubles in patients with syndrome of Carney complex $(21 \%)(7,26)$. We observed 4 recurrences $(4.9 \%)$ in our study including one patient with Carney complex syndrome whom recurred and operated two times.

Adjuvant therapy (radiation therapy or/and chemotherapy) can be used in some cases of malignancy. Habertheuer et al. showed that patients with malignant cardiac tumors who underwent adjuvant chemotherapy or/and radiation had a significantly better survival. (4) In our series, the decision of adjuvant therapy was given at interdisciplinary council and conducted for patients with recurrences of malignant tumors such as sarcomas. For patients with recurrences of myxomas we performed re-excision of the tumors. 
According to our analysis, it is evident that malignant tumors are more aggressive and have poor prognosis as have been previously reported. Interestingly, non-myxomatous benign tumors had similar survival to myxomas. Although the effects of gender, use of prosthetic material for defect closure and tumor location on survival were found to be statistically insignificant we identified ventriculotomy as a predictor of poor prognosis. In our opinion, the impact of ventriculotomy on poor survival may be due to the location of malignant tumors that mainly located in the ventricles.

To sum up, these tumors can be surgically treated with low morbidity and mortality. All benign tumors have survival that is similar to standard population. Nevertheless, these patients should be closely followed after surgical resection as they tend to recur. In contrast, malignant tumors have a dismal prognosis. Although we identified tumor histology and the ventriculotomy approach as the predictors of mortality, further studies should be performed to highlight other predictors of long-term outcome following surgical resection.

\section{Ethics}

Ethics Committee Approval: Hacettepe University NonInterventional Ethics Committee approval (G017 / 165-28).

Informed Consent: Because of the retrospective data screening, the patient the approval could not be obtained.

Peer-review: Externally peer-reviewed.

\section{Authoring Contributions}

Surgical and Medical Application: M.D., R.D., M.Y., M.G., Concept: U.K., Design: U.K., Data Collection or Processing: A.A., T.S., Analysis or Interpretation: U.K., Literature Search: T.S., A.A., by U.K.

Conflict of Interest: Conflict of Interest by Authors It is reported.

Financial Support: Financial support is provided by the authors.

\section{References}

1. Silverman NA. Primary cardiac tumors. Ann Surg. 1980;191:127-138.

2. Elbardissi AW, Dearani JA, Daly RC, et al. Survival after resection of primary cardiac tumors: a 48-year experience. Circulation. 2008;118:S7-15.

3. Simpson L, Kumar SK, Okuno SH, et al. Malignant primary cardiac tumors: review of a single institution experience. Cancer. 2008;112:2440-2446.

4. Habertheuer A, Laufer G, Wiedemann D, et al. Primary cardiac tumors on the verge of oblivion: a European experience over 15 years. J Cardiothorac Surg. 2015;10:56.

5. Keeling IM, Oberwalder P, Anelli-Monti M, et al. Cardiac myxomas: 24 years of experience in 49 patients Eur J Cardiothorac Surg. 2002;22:971-977.

6. Cetin G, Gursoy M, Ugurlucan $M$, et al. Single-institutional 22 years experience on cardiac myxomas. Angiology. 2010;61:504-509.

7. Garatti A, Nano G, Canziani A, et al. Surgical excision of cardiac myxomas: twenty years experience at a single institution. Ann Thorac Surg. 2012;93:825-831.

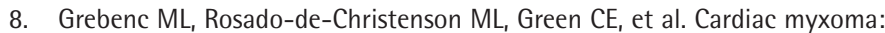
imaging features in 83 patients. Radiographics. 2002;22:673-162.

9. Elbardissi AW, Dearani JA, Daly RC, et al. Embolic potential of cardiac tumors and outcome after resection: a case-control study. Stroke. 2009;40:156-62.

10. Bruce CJ. Cardiac tumours: diagnosis and management. Heart. 2011;97:151160.

11. Paraskevaidis IA, Michalakeas CA, Papadopoulos $\mathrm{CH}$, et al. Cardiac tumors. ISRN Oncol. 2011;2011:208929.

12. Araoz PA, Mulvagh SL, Tazelaar $H D$, et al. CT and MR imaging of benign primary cardiac neoplasms with echocardiographic correlation. Radiographics. 2000;20:1303-1319.

13. Lobo A, Lewis JF, Conti CR. Intracardiac masses detected by echocardiography: case presentations and review of the literature. Clin Cardiol. 2000;23:702708.

14. Hirota M, Ishikawa N, Oi M, et al. Large primary cardiac sarcoma on the left ventricular free wall: is total excision contraindicated? Interact Cardiovasc Thorac Surg. 2010;11:670-672.

15. Jha NK, Khouri M, Murphy DM, et al. Papillary fibroelastoma of the aortic valve--a case report and literature review. J Cardiothorac Surg. 2010;5:84.

16. Stevens $L M$, Lapierre $H$, Pellerin $M$, et al. Atrial versus biatrial approaches for cardiac myxomas. Interact Cardiovasc Thorac Surg. 2003;2:521-525.

17. Mishra A, Shah M, Sharma $P$, et al. Operative management of intracardiac myxomas: A single center experience. Med J Armed Forces India. 2014;70:59.

18. Chitwood WR, Jr. Cardiac neoplasms: current diagnosis, pathology, and therapy. J Card Surg. 1988;3:119-154.

19. Disesa VJ, Collins JJ, Jr, Cohn LH. Considerations in the surgical management of left atrial myxoma. J Card Surg. 1988;3:15-22.

20. Hua A, Shemin RJ, Gordon JP, et al. Minimally invasive robotically assisted surgical resection of left atrial endocardial papillary fibroelastomas. J Thorac Cardiovasc Surg. 2014;148:3247-3249.

21. Owais TA, Färber G, Garbade J, Excision of a left atrial myxoma via a minimally-invasive technique: a possible routine access. nteract Cardiovasc Thorac Surg. 2011;12:875-877.

22. Ipek $G$, Erentug $V$, Bozbuga $N$, et al. Surgical management of cardiac myxoma. J Card Surg. 2005;20:300-304.

23. Gerbode F, Kerth WJ, Hill JD. Surgical management of tumors of the heart. Surgery. 1967;61:94-101.

24. St John Sutton MG, Mercier LA, Giuliani ER, et al. Atrial myxomas: a review of clinical experience in 40 patients. Mayo Clin Proc. 1980;55:371-376.

25. Blondeau P. Primary cardiac tumors--French studies of 533 cases. Thorac Cardiovasc Surg. 1990;38 Suppl 2:192-195.

26. McCarthy PM, Piehler JM, Schaff HV, et al. The significance of multiple, recurrent, and "complex" cardiac myxomas. J Thorac Cardiovasc Surg. 1986;91:389-396. 